\title{
The neuropharmacology of the age-old sedative/hypnotic, ethanol
}

\author{
Glenn W. Stevenson ${ }^{1}$ and Meredith A. Fox ${ }^{2 *}$ \\ Department of Psychology, University of New England, Biddeford, ME, USA \\ ${ }^{2}$ Laboratory of Clinical Science, National Institute of Mental Health, National Institutes of Health, Bethesda, MD, USA \\ *Correspondence:mfox@mail.nih.gov
}

Edited by:

Nicholas M. Barnes, University of Birmingham, UK

\section{A commentary on}

Ethanol activation of protein kinase A regulates $\mathrm{GABA}_{\mathrm{A}}$ receptor subunit expression in the cerebral cortex and contributes to ethanol-induced hypnosis

by Kumar, S., Ren, Q., Beckley, J. H., O'Buckley, T. K., Gigante, E. D., Santerre,

J. L., Werner, D. F., and Morrow, A. L. (2012). Front. Neurosci. 6:44. doi: 10.3389/fnins.2012.00044

Ethyl alcohol (ethanol) is produced by the process of fermentation whereby plant sugars are converted to ethanol by yeast. Products of fermentation include mead from honey, wine from grapes, sake from rice, and beer from grains. Fermented products can also be distilled, for example when whisky is distilled from grains (Herbst and Herbst, 2003). The history of voluntary ethanol use by humans dates as far back as 8000 years ago for wine and possibly earlier for beer, as barley may have been the oldest cultivated grain (Pendell, 2010). It is also documented that ethanol was an extremely important staple to ancient civilizations such as the Egyptians and the Maya (Johnson, 1994), as well as more modern societies such as the original American colonies (Pendell, 2010). It seems that modern society's interest in alcohol has certainly not waned, and from the standpoint of neuropharmacology, has probably increased.

During the past several decades, there has been a concerted effort to determine the neuropharmacological mechanism of action(s) of ethanol. Ethanol has been reported to produce its effects via modulation of neural cell membrane fluidity as well as modulation of several neurotransmitter systems, including $\gamma$-amino butyric acid (GABA), glutamate, dopamine, and opioid systems (for reviews, see Koob et al., 1998; Kumar et al., 2009). GABA is an inhibitory amino acid neurotransmitter that is ubiquitously distributed in the mammalian brain, and ethanol's effects on the GABA system are thought to be mediated primarily by activating the $\mathrm{GABA}_{\mathrm{A}}$ receptor, a 5-subunit receptor that gates $\mathrm{Cl}^{-}$ions (for a review, see Kumar et al., 2009). Thus, GABA receptor activation produces CNS inhibition via $\mathrm{Cl}^{-}$influx. It has also been reported that specific $\mathrm{GABA}_{\mathrm{A}}$ receptor subunits mediate specific effects. For example, the $\alpha 1$ subunit is associated with sedation, whereas the $\alpha 2$ and $\alpha 3$ subunits are associated with antianxiety effects (Licata and Rowlett, 2008; Ator et al., 2010). Many types of sedativehypnotic compounds (drugs producing dose-dependent sedation and ultimately sleep), including the benzodiazepines, barbiturates, and ethanol, bind to and activate the $\mathrm{GABA}_{\mathrm{A}}$ receptor, and it is reasonable to assume that the sedative effects of these agents are mediated, at least in part, by the $\alpha 1$ subunit.

It is known that neurotransmitters, including GABA, bind to their receptors as "first messengers," and initiate a complex cascade of intra-cellular events. In the case of GABA, part of this cellular cascade includes modulation of the "second messenger" systems $\mathrm{Ca}^{++}$and cAMP that ultimately modulate two protein kinases, $\mathrm{PKC}$ and PKA, resulting in myriad effects in the cell, including changes to gene expression (Moss et al., 1992; Diamond and Gordon, 1997; Brandon et al., 2000 for a review, see Kumar et al., 2009).

Leslie Morrow and colleagues have been exploring the complex cascade of downstream cellular events mediated by ethanol-induced $\mathrm{GABA}_{\mathrm{A}}$ receptor activation. In their recent Frontiers in Neuroscience report (Kumar et al., 2012), this research team determined the effects of acute ethanol exposure on PKAmediated $\mathrm{GABA}_{\mathrm{A}}$ receptor expression. Although chronic ethanol exposure has been reported to produce down-regulation and/or desensitization of $\mathrm{GABA}_{\mathrm{A}}$ receptors, Morrow and colleagues reported an interesting finding of acute ethanol exposure. Specifically, acute intracerebroventricular administration of ethanol produced dose-dependent increases in expression of PKA and $\mathrm{GABA}_{\mathrm{A}}$ receptor $\alpha 1$ subunits. In addition, antagonism studies revealed that blockade of PKA blocked the ethanol-induced increases in $\mathrm{GABA}_{\mathrm{A}}$ receptor $\alpha 1$ subunit expression, providing further evidence for a PKA-GABA receptor network communication. An additional manipulation showed that enhancing PKA activity actually enhanced ethanol-induced loss of righting reflex. Together with earlier reports from this research group, these data indicate that PKA (Kumar et al., 2012) and PKC (Kumar et al., 2006) may have antagonistic effects on $\mathrm{GABA}_{\mathrm{A}}$ receptor $\alpha 1$ subunit expression, thus delineating specific potential pathway(s) for mediation of ethanol effects on cell function and overt organismal behavior. This group's current report represents a comprehensive analysis of the specific effects of ethanol on kinase activity and receptor subunit expression levels, and adds another layer of knowledge about the neuropharmacological mechanisms of ethanol. It is quite possible that further elucidation of the complex molecular "systems level" analysis of ethanol's actions in nerve cells may yield important "systems level" approaches and advances for the treatment of alcohol abuse and dependence. 


\section{ACKNOWLEDGMENTS}

Meredith A. Fox was supported by the National Institute of Mental Health (NIMH) Intramural Research Program.

\section{REFERENCES}

Ator, N. A., Atack, J. R., Hargreaves, R. J., Burns, D., and Dawson, G. R. (2010). Reducing abuse liability of GABAA/Benzodiazepine ligands via selective partial agonist efficacy at $\alpha 1$ and $\alpha 2 / 3$ subtypes. J. Pharmacol. Exp. Ther. 332, 4-16. doi: 10.1124/jpet.109.158303

Brandon, N. J., Delmas, P., Kittler, J. T., McDonald, B. J., Sieghart, W., Brown, D. A., et al. (2000). GABAA receptor phosphorylation and functional modulation incortical neurons by a protein kinase C-dependent pathway. J. Biol. Chem. 275, 38856-38862.

Diamond, I., and Gordon, A. S. (1997). Cellular and molecular neuroscience of alcoholism. Physiol. Rev. 77, 1-20.

Herbst, R., and Herbst, S. T. (2003). The Wine Lover's Companion. 2nd edn. Hauppauge, NY: Barron's Educational Series.

Johnson, H. (1994). The World Atlas of Wine. 4th edn. New York, NY: Simon and Schuster.
Koob, G. F., Roberts, A. J., Schulteis, G., Parsons, L. H., Heyser, C. J., Hyytiä, P., et al. (1998). Neurocircuitry targets in ethanol reward and dependence. Alcohol. Clin. Exp. Res. 22, 3-9. doi: 10.1111/j.1530-0277.1998.tb03611.x

Kumar, S., Lane, B. M., and Morrow, A. L. (2006). Differential effects of systemic ethanol administration on protein kinase cepsilon, gamma, and beta isoform expression, membrane translocation, and target phosphorylation: reversal by chronic ethanol exposure. J. Pharmacol. Exp. Ther. 319, 1366-1375. doi: 10.1124/jpet.106.110890.

Kumar, S., Porcu, P., Werner, D. F., Matthews, D. B., Diaz-Granados, J. L., Helfand, R. S., et al. (2009). The role of $\operatorname{GABA}(\mathrm{A})$ receptors in the acute and chronic effects of ethanol: a decade of progress. Psychopharmacology 205, 529-564. doi: 10.1007/s00213-009-1562-z.

Kumar, S., Ren, Q., Beckley, J. H., O’Buckley, T. K., Gigante, E. D., Santerre, J. L., et al. (2012). Ethanol activation of protein kinase A regulates $\mathrm{GABA}(\mathrm{A})$ receptor subunit expression in the cerebral cortex and contributes to ethanolinduced hypnosis. Front. Neurosci. 6:44. doi: 10.3389/fnins.2012.00044s

Licata, S. C., and Rowlett, J. K. (2008). Abuse and dependence liability of benzodiazepine-type drugs: GABAA receptor modulation and beyond. Pharmacol. Biochem. Behav. 90, 74-89. doi: 10.1016/j.pbb.2008.01.001

Moss, S. J., Doherty, C. A., and Huganir, R. L. (1992). Identification of the cAMP-dependent protein kinase and protein kinase $\mathrm{C}$ phosphorylation sites within the major intracellular domains of the betal, gamma $2 \mathrm{~S}$, and gamma2L sub-units of the gamma-aminobutyric acid type A receptor. J. Biol. Chem. 267, 14470-14476.

Pendell, D. (2010). Pharmakopoeia: Power Plants, Poisons and Herbcraft. (Updated edn.). Berkeley, CA: North Atlantic Books.

Received: 18 April 2013; accepted: 25 June 2013; published online: 15 July 2013.

Citation: Stevenson GW and Fox MA (2013) The neuropharmacology of the age-old sedative/hypnotic, ethanol. Front. Neurosci. 7:122. doi: 10.3389/fnins. 2013.00122

Copyright (c) 2013 Stevenson and Fox. This is an openaccess article distributed under the terms of the Creative Commons Attribution License, which permits use, distribution and reproduction in other forums, provided the original authors and source are credited and subject to any copyright notices concerning any third-party graphics etc. 